\title{
IAMJ
}

INTERNATIONAL

AYURVEDIC

MEDICAL JOURNAL

(क) 2 (1)

\section{MANAGEMENT OF CASE OF PRIMARY HYPOTHYROIDISM ON THE PRINCIPLES OF DHATWAGNIMANDYA - A CASE REPORT}

\author{
$\underline{\text { Neetu Sharma }^{1} \text {, Shalini Rai }}{ }^{2}$, Sisir Kumar Mandal ${ }^{3}$, Anand More ${ }^{4}$ \\ ${ }^{1}$ P.G. Scholar, Department of Roga Nidana evum Vikriti Vigyana, All India Institute of Ayurveda, \\ New Delhi, India \\ ${ }^{2}$ Assistant Professor, Department of Roga Nidana evum Vikriti Vigyana, All India Institute of Ayurveda, \\ New Delhi, India \\ ${ }^{3}$ Professor, Department of Vikriti Vigyana, IMS, BHU, Varanasi, Uttar Pradesh, India \\ ${ }^{4}$ Professor, Department of Roga Nidana evum Vikriti Vigyana, All India Institute of Ayurveda, \\ New Delhi, India
}

Corresponding Author: neetu.sharma039@gmail.com

https://doi.org/10.46607/iamj16p6012021

(Published online: November 2021)

Open Access

(C) International Ayurvedic Medical Journal, India 2021

Article Received: 28/09/2021 - Peer Reviewed: 18/11/2021 - Accepted for Publication: 19/11/2021

Check for updates

\begin{abstract}
Hypothyroidism is a condition caused by thyroid hormone deficiency. It occurs due to hormonal imbalance \& decreased metabolism. Clinical manifestations range from no signs or symptoms to life-threatening conditions. In Ayurveda, it corresponds to Dhatvagni Mandya. In this case report the patient presented with puffiness of the face, swelling in both the limbs, muscle (back) pain, loss of appetite, constipation and abnormal weight gain. According to symptomatic presentations, the case was diagnosed as Dhatvagni mandya. Clinical presentation and biochemical parameter i.e., Thyroid Stimulating Hormone (TSH) was $12.07 \mathrm{uIU} / \mathrm{ml}$ which confirmed the case as Hypothyroidism in modern medicine. The multimodal Ayurvedic management approach incorporating ahara, vihara and aushadha was adopted. The case was treated on the line of principles of Agnimandya. Shaman Chikitsa (pacifying therapy) including internal administration of herbo-mineral formulations such as Arogyavardhini vati, Kanchnaar guggul, Punarnava mandur, Avipattikar churna, Swarna vanga along with a dietary regimen was prescribed to the patient. After 3 months' treatment, significant symptomatic relief along with reduction of serum TSH level $(3.05 \mathrm{uIU} / \mathrm{ml})$ without any adverse effects was observed in the patients. It can be inferred from the case that Ayurvedic intervention has enough potential to be employed and utilized in such endocrine disorders.
\end{abstract}

Keywords- Ayurveda, Dhatawagni, Agni, Hypothyroidism, Kanchnar Guggul, Arogyavardhini vati. 


\section{INTRODUCTION}

Thyroid diseases are among the commonest endocrine disorders worldwide. The prevalence of Hypothyroidism in India is $11 \%{ }^{[1]}$ which contributes to about 42 million people. ${ }^{[2]}$ The most common cause of hypothyroidism is the inability of the thyroid gland to produce a sufficient amount of thyroid hormone. ${ }^{[3]}$ Female gender and older age were found to have a significant association with hypothyroidism ${ }^{4}$. The idiopathic form of hypothyroidism occurs mainly in females older than 40 years. ${ }^{[4]}$ Hypothyroidism is not mentioned directly in Ayurvedic texts, but several references are found in various texts which can be correlated clinically to the pathogenesis of hypothyroidism. Signs \& symptoms of hypothyroidism can be correlated with symptoms of Dhatvagni Mandya. Acharya Vagbhata has given direct relation between Dhatvagni \& Jatharagni. All the dhatus has their separate Agni called Dhatvagni $\&$ are nothing but part of Jatharagni. So, with Jatharagni, Dhatvagni also gets manda (impaired). ${ }^{[5]}$ In the present case study, the symptoms of the patient can be compared with the symptoms of ama caused due to agnimandya. Clinical symptoms of agnimandya are Srotorodha (obstruction to body channels), Gaurava (heaviness), Anil Mudhata (Abnormal movement of Vata Dosha), Aalasya (laziness), Apakti (indigestion), Malasanga (obstruction of mala), Aruchi (loss of taste), Klama (lethargy). ${ }^{[6]}$ These symptoms can be correlated with patient's chief complaints. Thus, principles that correct the functioning of Agni will be beneficial in treating various pathologies. The treatment protocol was planned to keep in mind the state of rogabala and aturbala. The treatment was planned in such a way that it included amapachak, agnideepan, anuloman, medohara and kapha-vata shamaka properties. For this purpose, Arogyavardhini Vati 500mg, Punarnava Mandur 500mg, Kanchnaar Guggul 500mg twice a day and Avipattikar Churna 3grams and Swarna Vanga $250 \mathrm{mg}$ twice a day before the meal was advised for 3 months. (Image 1) The patient was also advised to follow the diet and lifestyle as per the principles of Ayurveda.

\section{Case Report}

A 45-year-old homemaker visited the Out-Patient Department of AIIA, New Delhi with the following chief complaints of puffiness of the face, swelling and stiffness in hands and legs (image 2), weakness, muscle (back) pain, laziness, loss of appetite, constipation and abnormal weight gain since last 1 year. She was advised for $\mathrm{Hb} \%$, blood sugar and thyroid profile. Based on laboratory investigation (image 3 ), she was diagnosed with primary hypothyroidism. No significant family history and history was found. She also had no history of any co-morbidities like hypertension, diabetes, cardiac problem or any other complicated diseases. The patient was having no addiction history. Appetite was subnormal and thirst was normal. His bowel was constipated. The bladder was regular, and sleep was disturbed.

Atura Bala Pramana was assessed by Dashavidha Pariksa. ${ }^{[13]}$ Prakriti of the patient was Kapha-Vataja and Vikriti was Kapha pradhan Vataja; Sara was Rakta; Samhana was Madhyam; Vyayama shakti was Avara; Ahara shakti and Jarana shakti was Avara; Satva was Avara; Satyama and Bala was Avara.

\section{Assessment criteria}

Improvement was assessed based on percentage relief observed in the presenting complaints. ${ }^{[14]}$ (table 2)

A symptom like acidity was assessed by Gastrointestinal Symptom Rating Scale (GSRS) ${ }^{[15]}$

\begin{tabular}{|l|l|l|}
\hline Severity & Score & Symptoms \\
\hline None & 0 & No symptoms \\
\hline Mild & 1 & Aware of symptoms, but easily tolerated \\
\hline Moderate & 2 & Discomfort is sufficient to cause interference with normal activities \\
\hline Severe & 3 & Incapacitating, with the inability to perform normal activities \\
\hline
\end{tabular}




\section{Observations and Results}

Considerable improvement was noticed in complaints (Table 1)

\section{DISCUSSION}

The change in lifestyle pattern of the current scenario has triggered several disharmonies in the biological system. Hypothyroidism is one such manifestation. The pathogenesis of Hypothyroidism is due to the abnormal functioning of Agni, which in turn affects Dhatvagni, eventually brings out the pathological sequence and ultimately the disease condition develops

Thus, dhatwagnimandya is the main causative factor in the manifestation of pathology of primary hypothyroidism. Jatharagni mandya once created can be treated easily but a vitiation of Dhatvagni is difficult to treat. (Image 4) Based on this disease chronicity \& its sadhya-asadhyta is decided. Moreover, a longer duration of treatment is needed to cure Ama at dhatu level. ${ }^{[16]}$ In this case, according to involved Doshas and samprapti, kapha-vata shamaka line of treatment was adopted. Prakriti and Vikriti was of same Doshas which makes it sadhya to treat but take a longer time duration. Along with that medohara chikitsa was also adopted which significantly shows lowering the BMI (body mass index) and thus, weight was also reduced from $78 \mathrm{kgs}$ to $75 \mathrm{kgs}$. Serum T.S.H. also reduced from $12.07 \mathrm{uIU} / \mathrm{ml}$ to 3.05 $\mathrm{uIU} / \mathrm{ml}$. (image 5) The patient's symptoms started reducing gradually and kept on reducing at the end of 3 months. But some symptoms like muscle pain and weakness persisted for a long and were gradually reduced. The swelling in the lower limbs was reduced. (Image 6) The patient was advised to follow a dietary and lifestyle regimen. She was also advised to do Ujjayi Pranayama. ${ }^{[17]}$

The medicines were discontinued after 3 months, and a repeat thyroid profile was done. The value of T.S.H. was found to be $3.43 \mathrm{uIU} / \mathrm{ml}$. (image7) Then she was advised to undergo a thyroid profile routinely to monitor the values. This shows the patient doesn't have to take the medications for the long term.

\section{CONCLUSION}

In the present case report, the patient was treated on the principles of dhatwagnimandya because the exact cause of primary hypothyroidism is unknown. There is a significant decrease in symptoms and TSH value of the patient within 3 months and does not increase after that. This shows the patient doesn't have to take the medicines for lifelong. Thus, it can be concluded that the combination of Arogyavardhini Vati, Kanchanar Guggul, Punarnava Mandur, Avipattikar Churna and Swarn Vanga was found to be effective in the successful management of a case of primary hypothyroidism without reporting any evidence of side effects or complications. The patient was also advised to practice yoga and pranayama which also helped in the reduction of body mass index and TSH. The above combination showed encouraging results in managing this case. This combination needs to be studied in a greater number of patients for better assessment.

\section{REFERENCES}

1. Bagcchi S: Lancet Diabetes Endocrinol: Hypothyroidism in India: more to be done. 2014 Oct; $2(10)$ :778.

2. Unnikrishnan AG, Menon UV, Indian Journal of Endocrinology Metabolism: Thyroid disorders in India: An epidemiological perspective. 2011 Jul;15(Suppl2): S78-81.

3. Patil N, Rehman A, Jialal I. Hypothyroidism. In: StatPearls [Internet]. Treasure Island (FL): StatPearls Publishing; 2021 [cited 2021 Aug 26]. Available from:

http://www.ncbi.nlm.nih.gov/books/NBK519536/

4. Unnikrishnan AG, Kalra S, Sahay RK, Bantwal G, John M, Tewari N. Prevalence of hypothyroidism in adults: An epidemiological study in eight cities of India. Indian J Endocrinol Metab. 2013;17(4):647-52.

5. Ashtanga Hridaya, edited by Dr Anna Moreshwar Kunte, Chaukhambha Surbharati Prakashan, Varanasi, Reprint Edition, 2002 SutraSthana, Doshopakramniya Adhyaya, 13/23,24. Page no. 216

6. Charaka Samhita, Edited by Dr Brahmanand Tripathi, Chaukhambha Surbharati Prakashan, Varanasi, Reprint Edition 2009 Chikitsa Sthana, Gahani Dosha Chikitsa Adhyaya, 15/42,43. Page no. 559

7. Kaviraj Shri Govinda Das Sen, editor. Bhaishajyaratnavali, Kushtarogadhikara 54/111-117. Varanasi: Chaukhamba Prakashan, Page no. 871, Edition- 
2021, Publication- Chaukhambha Subharti Prakashan- Varanasi

8. Kaviraj Shri Govinda Das Sen, editor. Bhaishajyaratnavali, Pandurogadhikara 12/63-65. Varanasi: Chaukhamba Prakashan, Page no. 381, PublicationChaukhambha Subharti Prakashan- Varanasi

9. Prof. Padamshri Krishna Chunekar, editor. Bhava Prakash Nighantu, Guduchyadi Varga Chapter 6 (IV) verse 102-104, page no. 254, Edition-2020, Publication- Chaukhambha Orientalia

10. Kaviraj Shri Govinda Das Sen, editor. Bhaishajyaratnavali, Sotharogadhikara 42/24. Varanasi: Chaukhamba Prakashan, Page no.769, PublicationChaukhambha Subharti Prakashan- Varanasi

11. Kaviraj Shri Govinda Das Sen, editor. Bhaishajyaratnavali, Amlapittarogadhikara 56/24-28. Varanasi: Chaukhamba Prakashan, Page no. 903, Publication- Chaukhambha Subharti Prakashan- Varanasi

12. Kaviraj Shri Govinda Das Sen, editor. Bhaishajyaratnavali, Prameharogadhikara 37/164-167. Varanasi: Chaukhamba Prakashan, Page no. 712, Publication- Chaukhambha Subharti Prakashan- Varanasi
13. Nath P, Dwivedi RR, Mandal SK. Atura Bala Pramana Through Dasvidha Pariksha. Journal of Ayurveda 2009;3:35-54.

14. Mridul R, Thakar A. A comparative clinical study of Vamana and Virechana Karma along with Shamana therapy in the management of Hypothyroidism. Department of Panchakarma, IPGT \& RA, Thesis submitted to Gujarat Ayurved University, Jamnagar, 2016

15. Pawar VSD, Deshpande DMS: Agni, Dhatvagnimandya, Hypothyroidism: 2016;3

16. Junghard O, Wiklund I. Validation of a Four-Graded Scale for Severity of Heartburn in Patients with Symptoms of Gastroesophageal Reflux Disease. Value Health. 2008;11(4):765-70.

17. Dr S.Vinudha, B.N.Y.S, the efficacy of Ujjayi Pranayama on Hypothyroidism in adults - A randomized controlled trial, Department of Yoga Government Yoga\& Naturopathy Medical College \& Hospital, Arumbakkam, Chennai, 2016 - 2019

Table 1: Efficacy of therapy on chief complaints

\begin{tabular}{|l|l|l|l|l|}
\hline Symptoms & Before treatment & After 1 month & After 2 months & After 3 months \\
\hline Bodyweight & $78 \mathrm{kgs}$ & $78 \mathrm{kgs}$ & $76 \mathrm{kgs}$ & $75 \mathrm{kgs}$ \\
\hline BMI & $30.5 \mathrm{~kg} / \mathrm{m}^{2}$ & $30.5 \mathrm{~kg} / \mathrm{m}^{2}$ & $29.7 \mathrm{~kg} / \mathrm{m}^{2}$ & $29.3 \mathrm{~kg} / \mathrm{m}^{2}$ \\
\hline Swelling in lower limbs (in cms) & $39 \mathrm{cms}$ & $38.5 \mathrm{cms}$ & $38 \mathrm{cms}$ & $38 \mathrm{cms}$ \\
\hline Puffiness & 2 & 1 & 1 & 0 \\
\hline Weakness & 4 & 3 & 2 & 1 \\
\hline Lethargy & 2 & 2 & 1 & 0 \\
\hline Muscle pain & 3 & 2 & 2 & 1 \\
\hline Constipation & $\mathrm{F}_{2} \mathrm{C}_{1} \mathrm{~S}_{1}$ & $\mathrm{~F}_{1} \mathrm{C}_{1} \mathrm{~S}_{0}$ & $\mathrm{~F}_{0} \mathrm{C}_{1} \mathrm{~S}_{0}$ & $\mathrm{~F}_{0} \mathrm{C}_{1} \mathrm{~S}_{0}$ \\
\hline Acidity & 2 & 1 & 0 & 0 \\
\hline
\end{tabular}

Table 2: Scoring of symptoms

\begin{tabular}{|c|c|c|c|}
\hline Symptoms & Score & Symptoms & Score \\
\hline Puffiness & & Lethargy & \\
\hline Absent & 0 & Doing work satisfactorily with proper vigour in time & 0 \\
\hline Occasional & 1 & Doing work without desire but in time & 1 \\
\hline $\begin{array}{l}\text { Peri-orbital oedema in the morning re- } \\
\text { lieved later }\end{array}$ & 2 & $\begin{array}{l}\text { Doing work without desire, unsatisfactorily, with a lot of mental pressure } \\
\& \text { not in time }\end{array}$ & 2 \\
\hline Persistent & 3 & Not starting any work in his/her responsibility, doing little work very slow & 3 \\
\hline Weakness & & Does not have any initiation $\&$ not want to work even after pressure & 4 \\
\hline Able to exercise without difficulty & 0 & Muscle ache & \\
\hline Able to do mild exercise & 1 & No & 0 \\
\hline Able to do only mild work & 2 & Relieved by rest & 1 \\
\hline Able to do mild work with difficulty & 3 & Not relieved by rest. Relieved by external application & 2 \\
\hline Not able to do even mild work & 4 & Requires external application and internal medication & 3 \\
\hline $\begin{array}{l}\text { Unable to do even day to day routine } \\
\text { work }\end{array}$ & 5 & Present consistently & 4 \\
\hline
\end{tabular}




\begin{tabular}{|l|l|l|l|l|l|}
\hline Frequency (F) & & Consistency $(\mathbf{C})$ & & Straining (S) \\
\hline Once a day & 0 & Shithila & 0 & No & 0 \\
\hline Once in two days & 1 & Madhyama & 1 & Occasionally Bearable & 1 \\
\hline Once in three days & 2 & Kathina & 2 & Frequently, Severe & 2 \\
\hline Once in more than three days & 3 & Granthil & 3 & & \\
\hline
\end{tabular}

Image 1: Rationale of drug chosen for the study
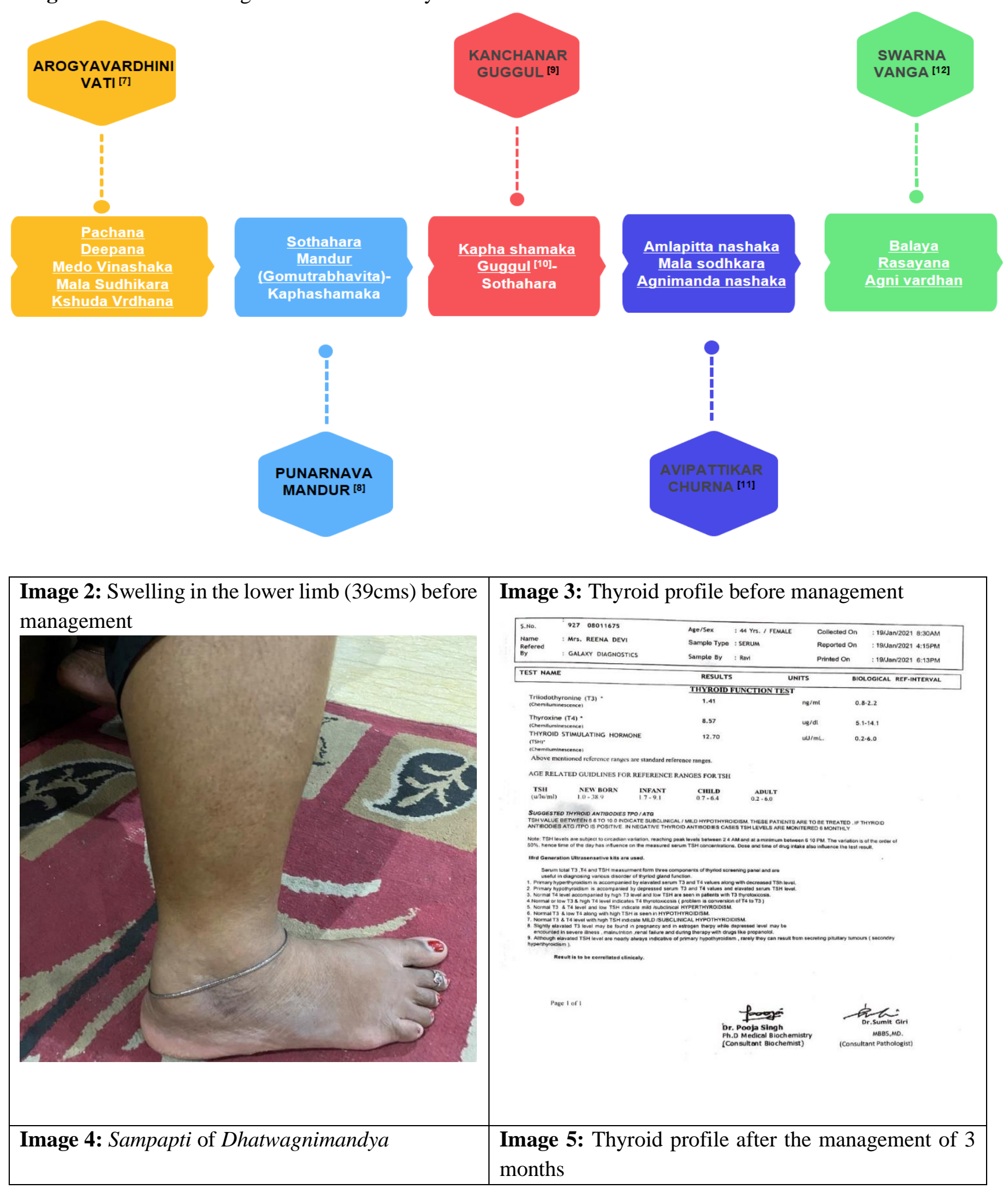


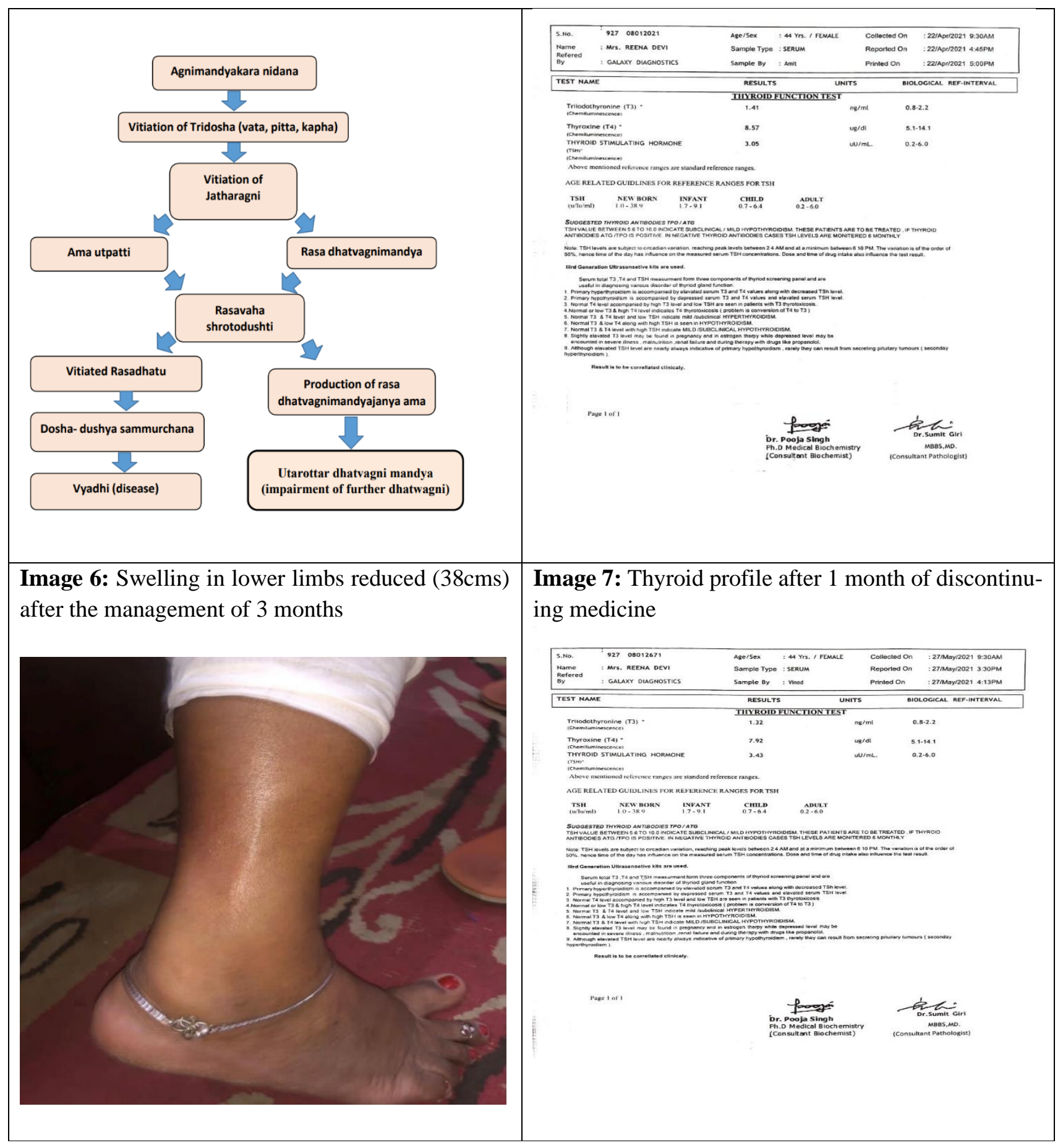

\section{Source of Support: Nil Conflict of Interest: None Declared}

How to cite this URL: Neetu Sharma et al: Management Of Case Of Primary Hypothyroidism On The Principles Of Dhatwagnimandya - A Case Report. International Ayurvedic Medical Journal \{online\} 2021 \{cited November 2021\} Available from: http://www.iamj.in/posts/images/upload/3258_3263.pdf 